\title{
珪素鋼表面近傍の $\mathrm{MnS}$ の生成挙動*
}

\author{
井口征夫** 筋田成子吕 伊藤 庸 ${ }^{* *}$
}

J. Japan Inst.Metals, Vol.49, No.1(1985), pp.9-14

Formation of MnS in the Vicinity of Surface of Silicon Steel

Yukio Inokuti**, Shigeko Sujita** and Yo Ito**

Formation of $\mathrm{MnS}$ in the vicinity of the steel surface during annealing in $\mathrm{N}_{2}$ gas after final annealing and subsequent coating treatments of grain oriented silicon steel containing $\mathrm{MnS}$ as an inhibiter was investigated. The morphology of $\mathrm{MnS}$ was observed by a transmission electron microscope with extraction replicas, and the composition of $\mathrm{MnS}$ was determined by means of energy dispersive X-ray analysis, electron probe microanalysis and Auger electron spectroscopy. The results are as follows.

(1) $\mathrm{MnS}$ is formed preferentially in the vicinity of the steel surface after the annealing in $\mathrm{N}_{2}$ for duration more than $12 \mathrm{ks}$ in the temperature range between 1073 and $1173 \mathrm{~K}$. MnS has the plate-like or rod-like morphologies and is $0.1-5 \mu \mathrm{m}$ in size.

(2) Formation of $\mathrm{MnS}$ decreases drastically in $20 \mu \mathrm{m}$ depth from the steel surface, and no precipitates are observed in the central area.

(3) MnS does not contain impurity elements in precipitates themselves.

(4) The orientation relationship between $\mathrm{MnS}$ and silicon steel matrix is considered to satisfy relations of $(1 \overline{1} 1)_{\mathrm{MnS}} / /(110)_{\alpha}$ and $[1 \overline{1} \overline{2}]_{\mathrm{MnS}} / /[001]_{\alpha}$ or $(012)_{\mathrm{MnS}} / /(110)_{\alpha}$ and $[100]_{\mathrm{MnS}} / /[001]_{\alpha}$.

(Received May 16, 1984)

Keywords : manganese sulfide, precipitates, secondary recrystallization, near-surface, inhibiter, grain oriented silicon steel

\section{I. 緒言}

一方向性珪素鋼板は 2 次再結晶粒を(110) [001]，すなわ ち Goss 方位に高度に集積させたもので, 主として変圧器 そのほかの電気機器の鉄心として使用されている。このよ らな Goss 方位の 2 次再結晶粒を優先的に発達させるため に $\mathrm{MnS}^{(1)}, \mathrm{AlN}^{(2)}, \mathrm{MnSe}^{(3)}$ 等の 1 次再結晶粒成長抑制剂 (インヒビタ一)が使用されている.一方 2 次再結晶後にお いてこれらのインヒビターは乾 $\mathrm{H}_{2}$ 中での高温純化焼鈍に より絶縁被膜中あるいは被膜直下の鋼板表面近傍に濃縮さ せて製品の高純化を図っている(4).

従来珪素鋼中のインヒビターの析出挙動は 2 次再結晶集 合組織を制御するための重要因子であるためかなりの研 究(1)-(3)(5)-(7)が行なわれているが, 高温純化焼鈍以後の絶 縁被膜と鋼板表面近傍に括けるこれらインヒビタ一の挙動 に関しては全く知られていない.

本報は MnS をインヒビターとする珪素鋼の 2 次再結晶 焼鈍, 純化焼鈍括よびューティング被膜処理後 $\mathrm{N}_{2}$ 中で焼 鈍を施したときの鋼板表面近傍の $\mathrm{MnS}$ の生成挙動の調査 を行なったものである。

\section{II. 実 験 方 法}

真空溶解により溶製した $100 \mathrm{~kg}$ 鋼塊を熱延して $2.4 \mathrm{~mm}$ 厚とした. Table 1 は珪素鋼熱延板の化学成分を示すが, インヒビターとして MnSを用いている。この熱延板は $1223 \mathrm{~K}, 180 \mathrm{~s}$ の中間焼鈍処理をはさんで 2 回の冷間圧延 を施して $0.3 \mathrm{~mm}$ 厚の最終冷延板とした．次に湿 $\mathrm{H}_{2}$ 中で $1073 \mathrm{~K}, 300 \mathrm{~s}$ の脱炭・ 1 次再結晶焼鈍を行なった。 その後 鋼板表面に $\mathrm{MgO}$ を主成分とする焼鈍分離剤を塗布したの ち $\mathrm{N}_{2}$ 中で $1093 \mathrm{~K}$ から $1323 \mathrm{~K}$ まで $1.4 \times 10^{-3} \mathrm{~K} / \mathrm{s}$ で昇温 して 2 次再結晶焼鈍を施した後, 乾 $\mathrm{H}_{2}$ 中で $1473 \mathrm{~K}, 18 \mathrm{ks}$ の純化焼鈍を行ならと同時に鋼板表面にフォルステライト 系絶縁被膜を形成させた。この 2 次再結晶および純化焼鈍 を以後仕上焼鈍と呼ぶ。さらにこの絶縁被膜上にコロイダ Table 1 Chemical composition of the hot-rolled sheets of $100 \mathrm{~kg}$ ingot (mass $\%$ ).

\begin{tabular}{c|c|c|c|c|c|c|c}
\hline \hline $\mathrm{C}$ & $\mathrm{Si}$ & $\mathrm{Mn}$ & $\mathrm{P}$ & $\mathrm{S}$ & $\mathrm{Ti}$ & $\mathrm{N}$ & $\mathrm{O}$ \\
\hline 0.039 & 3.00 & 0.070 & 0.008 & 0.018 & 0.002 & 0.0030 & 0.0015 \\
\hline
\end{tabular}

** 川崎製鉄株式会社技術研究所 (Research Laboratories, Kawasaki Steel Corp., Chiba)

* 1982 年 10 月日本金属学会札幌大会に一部発表 
ルシリカとりん酸塩とを主成分とするコーティング被膜を 施した後, $\mathrm{N}_{2}$ 中で $873 \mathrm{~K}$ から $1373 \mathrm{~K}$ ま゙の温度範囲で $600 \mathrm{~s}$ から $120 \mathrm{ks}$ の焼鈍を行ない MnS の析出状態を変党 た.

次に鋼板表面近傍の析出物の電顕観察は抽出レプリカに より次の手順で試料の作製を行なった。きず $353 \mathrm{~K}$ の $30 \%$ 可性ソーダ液中に浸漬してコーティング被膜を除去後, $573 \mathrm{~K}$ の溶融可性ソーダ液中に浸漬してフォルステライト 系絶縁被膜を除去した，次に $3 \% \mathrm{HF}$ と $\mathrm{H}_{2} \mathrm{O}_{2}$ との混合液で 表面から $5 \mu \mathrm{m}, 10 \mu \mathrm{m}, 20 \mu \mathrm{m}$ および $150 \mu \mathrm{m}$ (中心層) 化学 研摩後 Speed 法 ${ }^{(9)}$ により電解エッチングを行ない抽出レプ リカ試料を作製し透過電顕 (H-600 特よび H-700) 観察を行 なった。 また析出物の元素分析はSTEM と組合せた $\operatorname{EDX}^{(10)(11)}$ (Energy Dispersive X-ray Analyzer, JEM100C), EPMA (Electron Probe Micro Analysis, EMX$\mathrm{SM})$ および $\mathrm{AES}^{(12)}$ (Auger Electron Spectroscopy, PHI595)を用いた。

\section{III. 実 験 結 果}

\section{1. 表面近傍の $\mathrm{MnS}$ の形態}

Fig. 1 は仕上燒鈍後, $\mathrm{N}_{2}$ 中で $1073 \mathrm{~K}, 36 \mathrm{ks}$ の焼鈍を施 した後試料表面から約 $10 \mu \mathrm{m}$ 深さから抽出レプリカ法に より得られた析出物の電顕写真执よびその電子線回折像を 示す.Fig.1 には幅約 $0.4 \mu \mathrm{m}$, 長さ約 $8 \mu \mathrm{m}$ の板状の大き な析出物が箕察される。電子線回折像からこの析出物は格 子定数 $a=0.5224 \mathrm{~nm}$ の岩塩型構造の $\alpha-\mathrm{MnS}$ と同定され た。またこの $\mathrm{MnS}$ は [111] が入射電子線に平行であり，
板状の析出物の長手方向(おそらく成長方向) は [112] であ る.これら 10 例の $\mathrm{MnS}$ 電子線回折像中 6 例が Fig.1 と同 様の回折像が得られた。しかし 4 例の MnS は [012]が入 射電子線に平行で，板状の析出物の成長方向は [100] であ った.

Fig. 2 は 2 次再結晶焼鈍前の湿 $\mathrm{H}_{2}$ 中で $1073 \mathrm{~K}, 300 \mathrm{~s}$

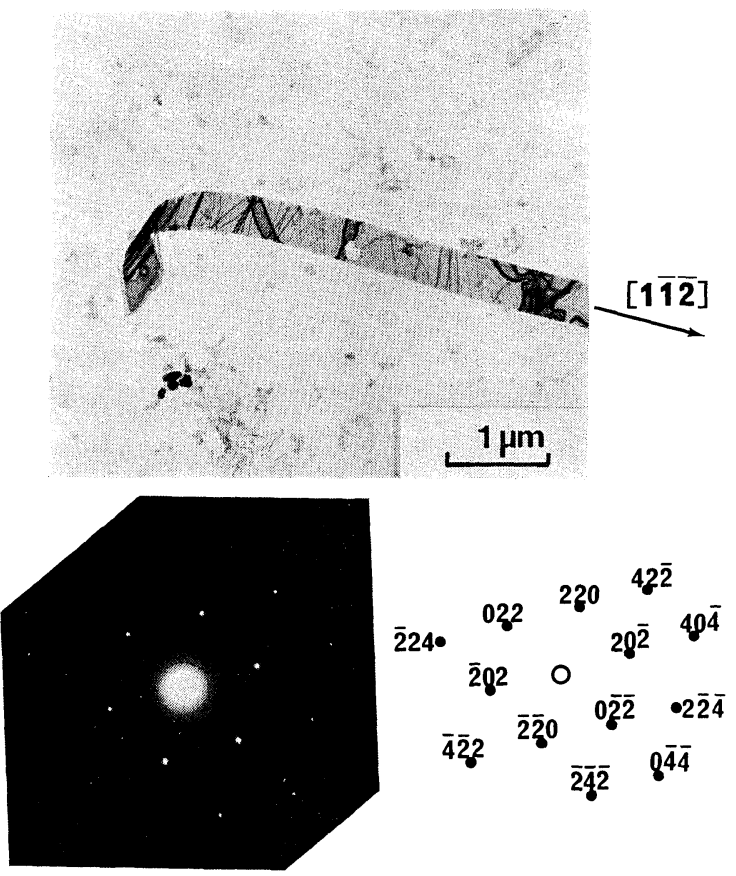

Fig.1 Electron micrograph and diffraction pattern of $\mathrm{MnS}$ formed in $10 \mu \mathrm{m}$ depth from the steel surfce.

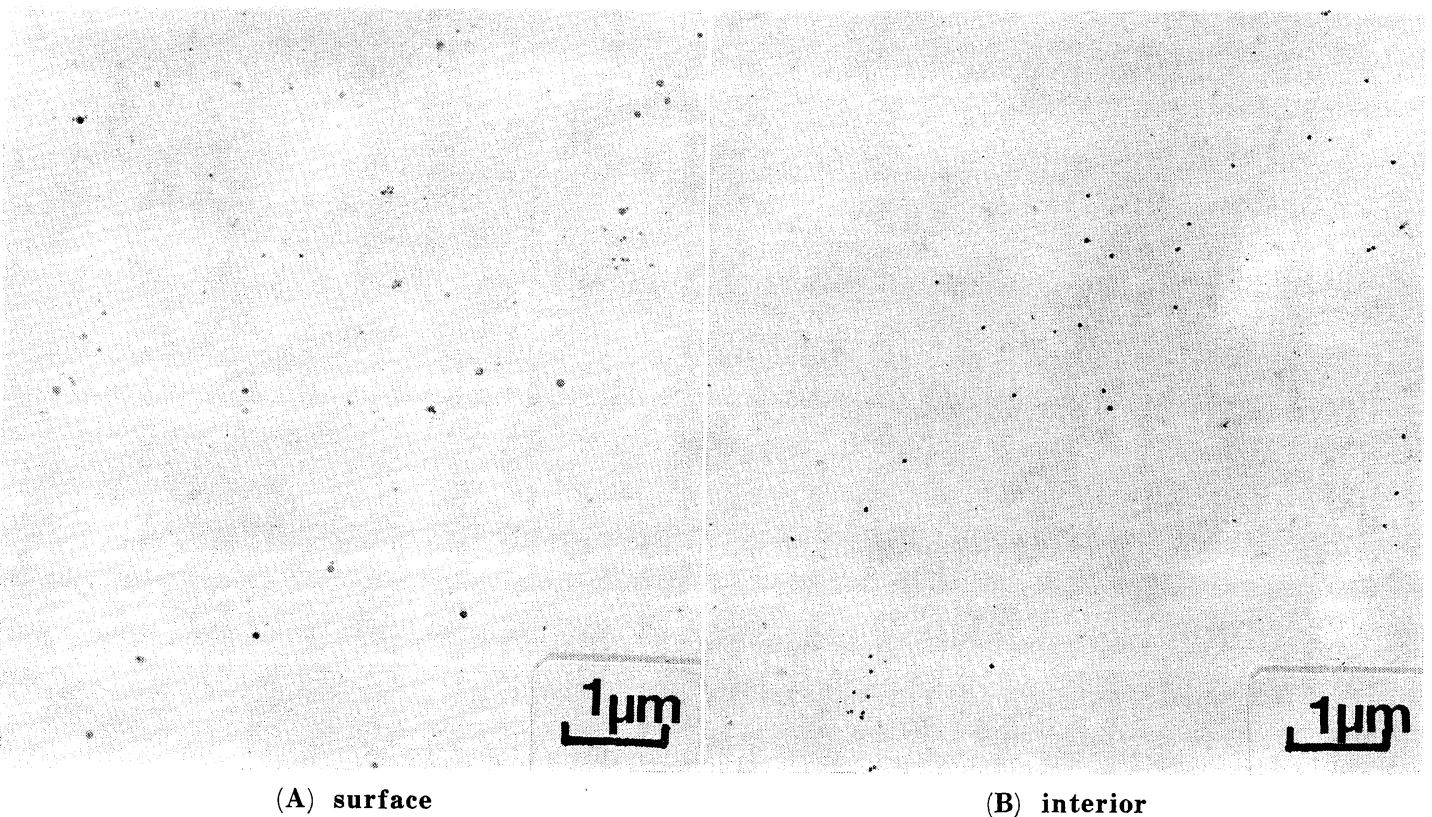

Fig.2 MnS dispersion in the as-decarburized and primary recrystallized silicon steel, prior to the secondary recrystallization. 
の脱炭・ 1 次再結晶焼鈍を行なったときの鋼板表面近傍お よび中心層から抽出レプリカ法により得られた MnS の電 顕写真である.Fig.2 に拈いて 30〜100 nm 程度の微細な $\mathrm{MnS}$ が均一に分散している。この結果は通常珪素鋼中で インヒビターとして利用している $\mathrm{MnS}$ の大きさと同程度 である(1)。また Fig.2 の表面近傍の MnS は中心層よりも 若干大きい。これに対して，本実験の Fig.1の仕上焼鈍後 の $\mathrm{N}_{2}$ 中での焼鈍により表面近傍に析出した MnS は Fig.2 の $\mathrm{MnS}$ に比較して極端に大さいことが注目される。

\section{2. 表面近傍の $\mathrm{MnS}$ の生成条件}

Fig.3 は仕上焼鈍後, $\mathrm{N}_{2}$ 中で $873 \mathrm{~K}$ から $1373 \mathrm{~K}$ までの 温度範囲で $600 \mathrm{~s}$ から $120 \mathrm{ks}$ の焼鈍を行なったときの電顕 観察による表面近彦の MnS の析出状況を示す. Fig. 3 か ら MnS は $1073 \mathrm{~K}$ から $1173 \mathrm{~K}$ の温度範囲で $1.8 \mathrm{ks}$ 以上 の焼鈍で析出するが，12 ks 以上の焼鈍では大量に析出す る.

Fig.4 は $\mathrm{N}_{2}$ 中で $1073 \mathrm{~K}, 36 \mathrm{ks}$ の焼鈍を行なった後の 表面から深さ方向の MnS の電顕写真を示す. 表面から $5 \mu \mathrm{m}$ 深さのごく表面近傍において $0.1 \sim 0.5 \mu \mathrm{m}$ 程度の球 状あるいは塊状と幅 $4 \mu \mathrm{m}$, 長さ $2.5 \mu \mathrm{m}$ 程度の板状の

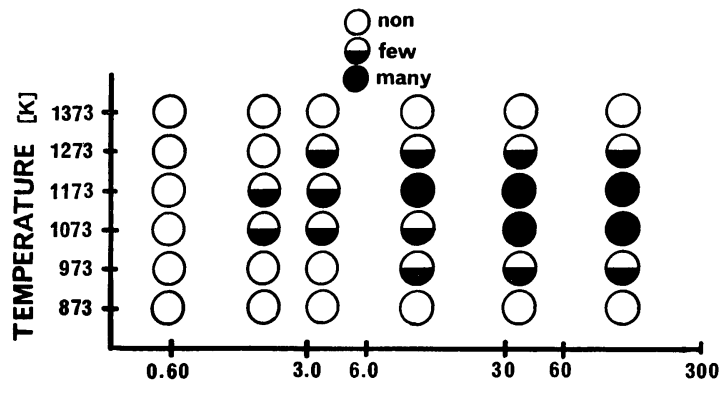

ANNEALING TIME [ks]

Fig.3 Formation of $\mathrm{MnS}$ in the vicinity of the steel surface of silicon steel after the annealing in $\mathrm{N}_{2}$ gas at $873-1373 \mathrm{~K}$ for $0.6-120 \mathrm{ks}$.

( A)

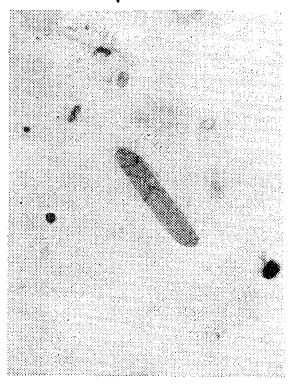

$5 \boldsymbol{\mu m}$ depth
(B)

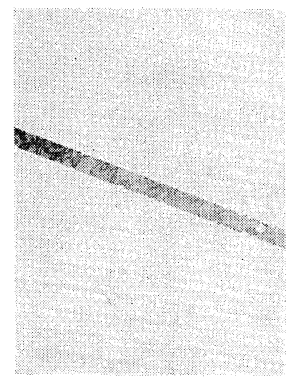

$10 \mu \mathrm{m}$ depth

MnS が混在している. 表面から $10 \mu \mathrm{m}$ 深さに打いて幅 $0.4 \mu \mathrm{m}$, 長さ $6 \mu \mathrm{m}$ (最大長さで $10 \mu \mathrm{m}$ )の板状の大きな $\mathrm{MnS}$ が観察される。表面から $20 \mu \mathrm{m}$ 深さに打いて MnS は最大なもので幅 $0.2 \mu \mathrm{m}$, 長さ $4 \mu \mathrm{m}$ であるが, $10 \mu \mathrm{m}$ 深 さの MnS に比べて小さく，数もきわめて少ない。また鋼 板の中心附近では MnS が全く観察されない.

\section{3. 表面近傍の $\mathrm{MnS}$ の組成}

Fig. 5 は仕上焼鈍後 $\mathrm{N}_{2}$ 中で $1073 \mathrm{~K}, 36 \mathrm{ks}$ 焼鈍後表面 から $10 \mu \mathrm{m}$ 深さの MnS の STEM 拈よびEDXによる析出
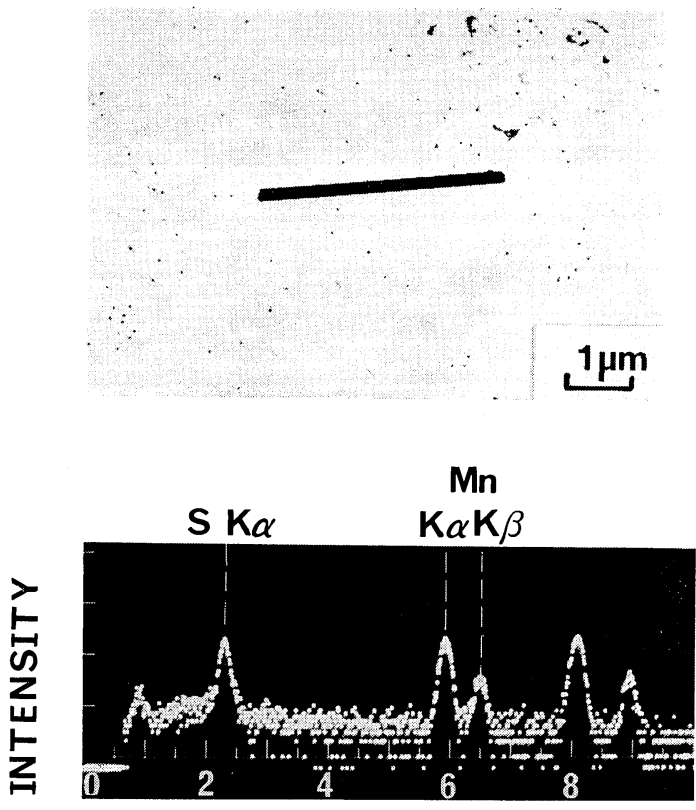

\section{ENERGY [keV $]$}

Fig.5 STEM of $\mathrm{MnS}$ and its spectrum of EDX formed in $10 \mu \mathrm{m}$ depth from the steel surface after the annealing in $\mathrm{N}_{2}$ gas at $1073 \mathrm{~K}$ for $36 \mathrm{ks}$.

( C )

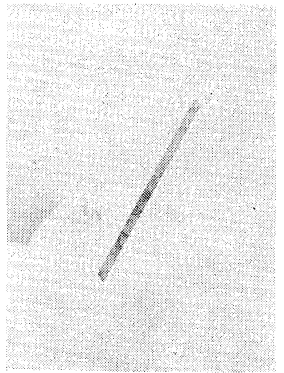

$20 \mu \mathrm{m}$ depth
(D)

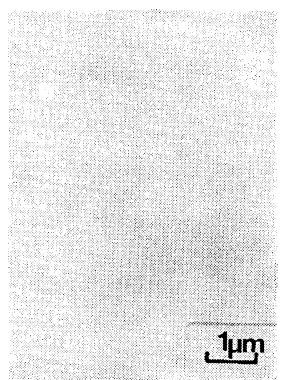

Central area

\section{from the steel surface}

Fig.4 Variation of MnS formation through the thickness from the steel surface after the annealing in $\mathrm{N}_{2}$ gas at $1073 \mathrm{~K}$ for $36 \mathrm{ks}$. 
物の分析スペクトルを示す。分析スペクトルから $\mathrm{SK}_{\boldsymbol{\alpha}}$ $(2.31 \mathrm{keV}), \mathrm{MnK}_{\boldsymbol{\alpha}}(5.90 \mathrm{keV})$ および $\mathrm{MnK}_{\boldsymbol{\beta}}(6.49 \mathrm{keV})$ の ピークが検出される。このほか $\mathrm{CuL}_{\alpha}(0.92 \mathrm{keV}), \mathrm{CuK}_{\boldsymbol{\alpha}}$ $(8.05 \mathrm{keV})$ 扣よび $\mathrm{CuK}_{\beta}(8.90 \mathrm{keV})$ のピークが検出された が，これらのピークは観察試料の $\mathrm{Cu}$ メッュによるもの である。

Fig. 6 は Fig. 5 と同様の処理後の表面からの $5 \mu \mathrm{m}$ 深さ の MnS の EPMA による結果を示すが, 板状と塊状の析 出物からは共に Mn と S が検出される。

Fig.7 は Figs. 5 および 6 と同様の処理後の表面から $5 \mu \mathrm{m}$ 深さの MnS の反射電子 (Reflection Electron) 像と才 ージェスペクトルを示す，スペクトルから S, C, O, Mn， $\mathrm{Cu}$ が検出される。これらの検出元素のらちで C 抽出レプリカ試料, Oは試料抽出中の酸化, $\mathrm{Cu}$ は $\mathrm{Cu}$ × ッシュによるものである.

Kiessling と Westman ${ }^{(13)}$ は Mn とS 粉末を用いて 1423 $\mathrm{K}$ で 86-172 ks の焼鈍により生成した析出物は $\alpha-\mathrm{MnS}$ 中 に Ti, V, Cr 等の遷移金属 $(\mathrm{Me})$ を含有した $(\mathrm{Mn}, \mathrm{Me}) \mathrm{S}$ の組成となることを報告している。これに対して本実験で の表面近傍に優先析出した析出物の組成は Mn と S 元素し か検出されなく純粋の MnS であることが注目される。

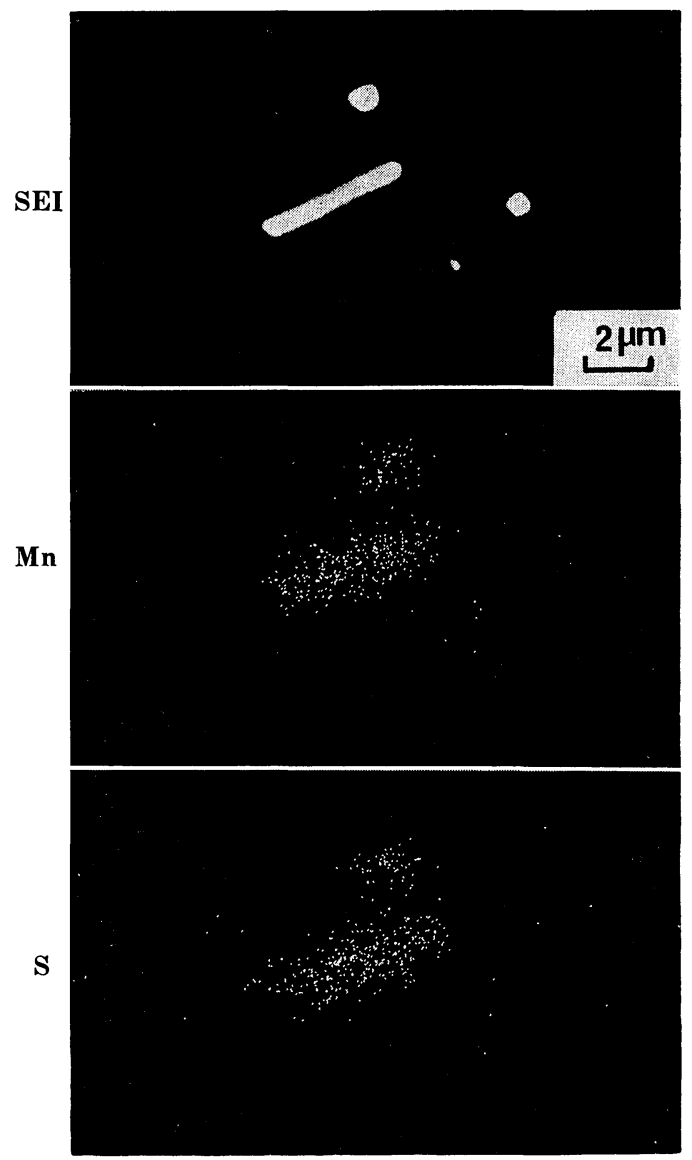

Fig.6 EPMA of MnS formed in $5 \mu \mathrm{m}$ depth from the steel surface after the annealing in $\mathrm{N}_{2}$ gas at $1073 \mathrm{~K}$ for $36 \mathrm{ks}$.
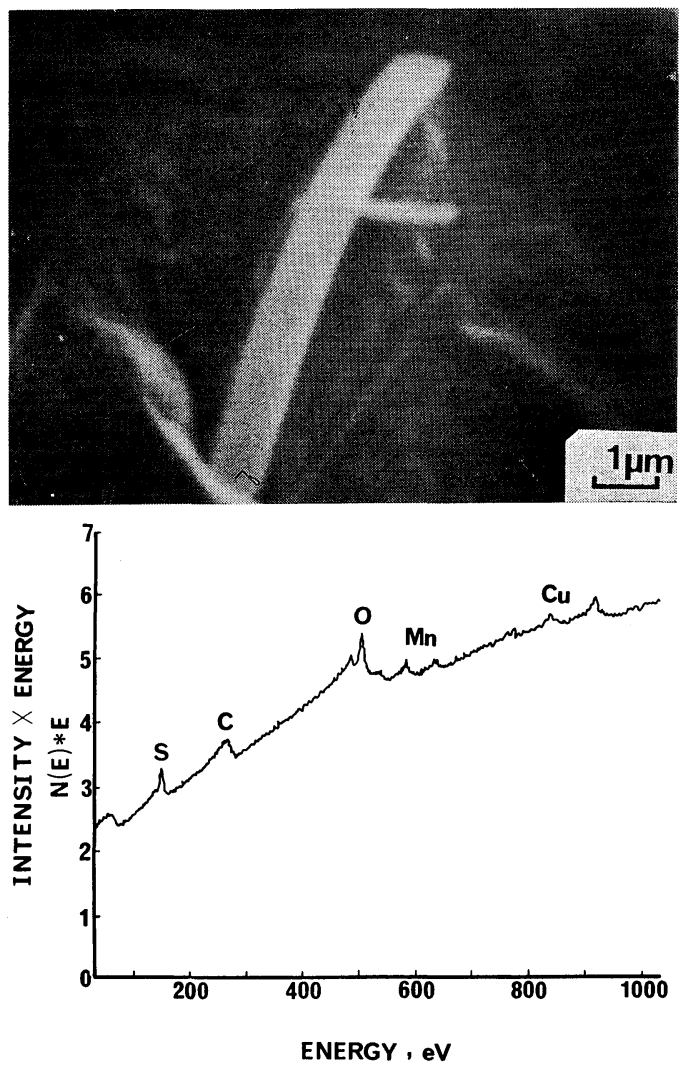

\section{Auger Spectrum}

Fig.7 Reflection Electron image of $\mathrm{MnS}$ and its Auger spectrum formed in $5 \mu \mathrm{m}$ depth from the steel surface after the annealing in $\mathrm{N}_{2}$ gas at $1073 \mathrm{~K}$ for $36 \mathrm{ks}$.

\section{IV. 考察}

\section{1. 表面近傍の $\mathrm{MnS}$ の優先析出}

一方向性珪素鋼板は磁気特性として磁束密度が高く，鉄 損が低いことが要求されている。このためには珪素鋼中の 2 次再結晶粒をGoss 方位に高度に集積させ，かつ鋼中に 残存する不純物や析出物をできる限り少なくする必要があ る. Fig. 8 は一方向性珪素鋼板の脱炭・ 1 次再結晶処理 (a) から本実験の仕上焼鈍後の $\mathrm{N}_{2}$ 中焼鈍 (f) に至るまでの 一連の実験工程に扣ける鋼板表面近傍の MnS の変化を模 式図で示したものである。まず，Fig.8の（a) は中間焼鈍 をはさんで 2 回の冷間圧延 ${ }^{(14)}$ を施して最終冷延板とした 後湿 $\mathrm{H}_{2}$ 中で脱炭・ 1 次再結晶焼鈍を施したときの状況を 示す.Fig. 2 に見られるように MnS がインヒビターとして 鋼板中に微細に均一に分散している。この MnS のインヒ ビター分散は 2 次再結晶を起すために正常粒成長を抑制す る分散不純物相の存在の必要性を指摘した May bull(1), Littmann と $\operatorname{Heck}^{(15)}$ との理念に基づくものであ る。またこの湿 $\mathrm{H}_{2}$ 中での脱炭・ 1 次再絬晶焼鈍時には鋼 板表面に $\mathrm{SiO}_{2}$ を主成分とするサブスケールが形成され 


\section{(a)As-decaburized and Primary Recrystallization}

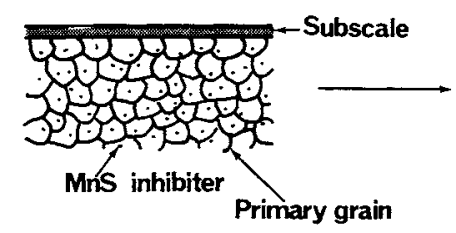

(b) MgO Separator

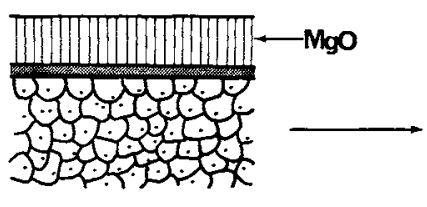

(c)Secondary Recrystallization

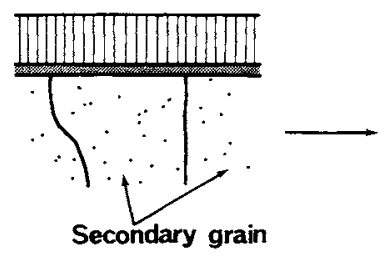

(d)Purification

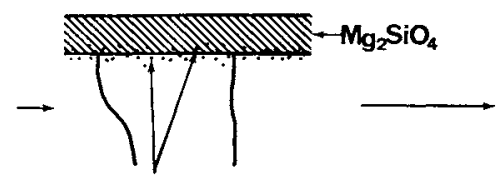

Fine MnS, FeS, solute S, etc.
(e)Coating

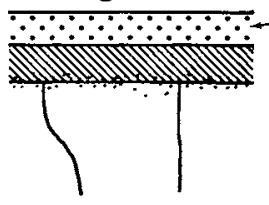

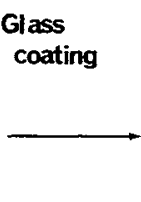

(f)Annealing in $\mathrm{N}_{2}$ Gas

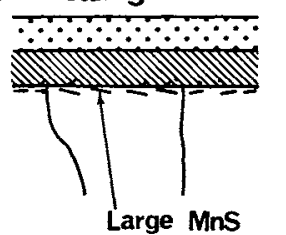

Fig.8 Schematic illustration for variation of $\mathrm{MnS}$ dispersion in the manufacturing processes after the as-decarburized and primary recrystallized treatment.

る(16).Fig.8の(b)で忙次の 2 次再結晶焼鈍の際に起る鋼 板同士の焼付を防止するため $\mathrm{MgO}$ を主成分とする燒鈍分

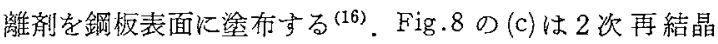
蛙鐩见よりGoss 方位に集積した 2 次再結晶粒を成長させ $ろ^{(17)(18)}$. 次の Fig.8の (d) では乾 $\mathrm{H}_{2}$ 中での高温純化焼鈍 を施してフォルステライト $\left(\mathrm{Mg}_{2} \mathrm{SiO}_{4}\right)$ 系絶縁被膜中あるい は被膜直下の鎆板表面近傍飞微細 MnS, Fes 西るいは固溶 S等の状態て濃縮させる(4)。またこのフォルステライト系 絶縁被膜は脱炭・ 1 次再結晶焼鈍後の鋼板表面纪形成され る $\mathrm{SiO}_{2}$ を主成分とするサブスケールと $\mathrm{MgO}$ を主成分とす る焼鈍分路剂を仕上焼鈍時に反応させることによって形成 される(19). Fig.8の(e)はフォルステライト系絶縁被膜の 上にガラス質の薄いコーティングを施し，珪素鋼板の確実 な絶縁珄の保証々鉄損古るいは磁歪特性の改善を図る(8). Fig.8の(f) は本研究で解明した通り， $N_{2}$ 中で焼鈍を行な らと表面近傍化大き $\mathrm{MnS}$ か $1073 \mathrm{~K}$ から $1173 \mathrm{~K}$ の温度

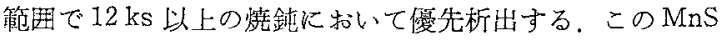
は表面から板厚方向 $20 \mu \mathrm{m}$ 程度にわた。て生成する.MnS は深さ $10 \mu \mathrm{m}$ 程度で最大長さ $10 \mu \mathrm{m}$ 程度に季で成長する が，さらに深くなると析出物は小さく，数す少なくなる。 そして中心附近では $\mathrm{MnS}$ が全く存在しないのが特徵であ る。この $\mathrm{MnS} の$ 表面への優先析出は十分解明されたわけ ではないが，鋼板表面上のフォルステライト系絶縁被膜が 存在しないと鋼板の純化が起りにくいことから年，この フォルステライト系總縁被膜の存在が大きな $\mathrm{MnS}$ の優先 析出に重要な役割を果していると考只られる。

\section{MnS と珪素鋼との整合関係}

珪素鋼中でインヒビターとして利用される $\mathrm{MnS}$ は徽細 に析出させるため $\mathrm{MnS}$ 之珪素鋼之の整合性の測定が困難 である、本実験から鋼板表面近傍に優先析出する大きな板
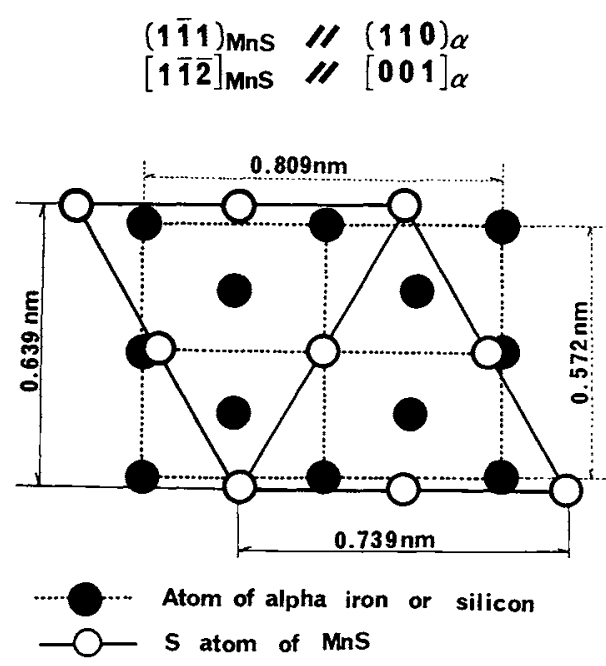

Fig.9 Schematic illustration of the orientation relationship of (11)1 $)_{\mathrm{MnS}} / /(110)_{\alpha}$ and $[1 \overline{1} \overline{2}]_{\mathrm{MnS}} / /[001]_{\alpha}$ between $\mathrm{MnS}$ and silicon steel matrix.

状の $\mathrm{MnS}$ は格子定数 $a=0.5224 \mathrm{~nm}$ の岩塩構造の $\alpha-\mathrm{MnS}$ であることが解明された。また電子線回折から MnSは [111]岁るいは[012]が入射電子線に平行であり，しかむ板 状の析出物の成長方向は $[1 \overline{1} \overline{2}]$ と[100]とが存在することが 明らかとなった。 Fig.9特よび10は MnS と珪素鋼、トり ックスとの整合関係を示したものである，Fig.9 Kおいて は珪素鋼の 2 次再結晶䊀が Goss 方位儿集積した結晶粒で あるから，MnS と珪素鋼との整合は(111) $\mathrm{MnS} / /(110)_{\alpha}$ ，

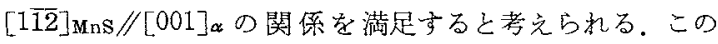
整合関係があるとすれば $\mathrm{MnS}$ と轨素銅とのずれの程度は

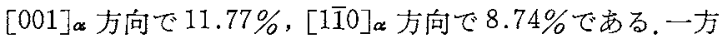
Fig.10飞怙いては $(012)_{\mathrm{MnS}} / /(110)_{\alpha},[100]_{\mathrm{MnS}} / /[001]_{\alpha}$ の関係を满足すると考光られる。この整合関係に执いては 

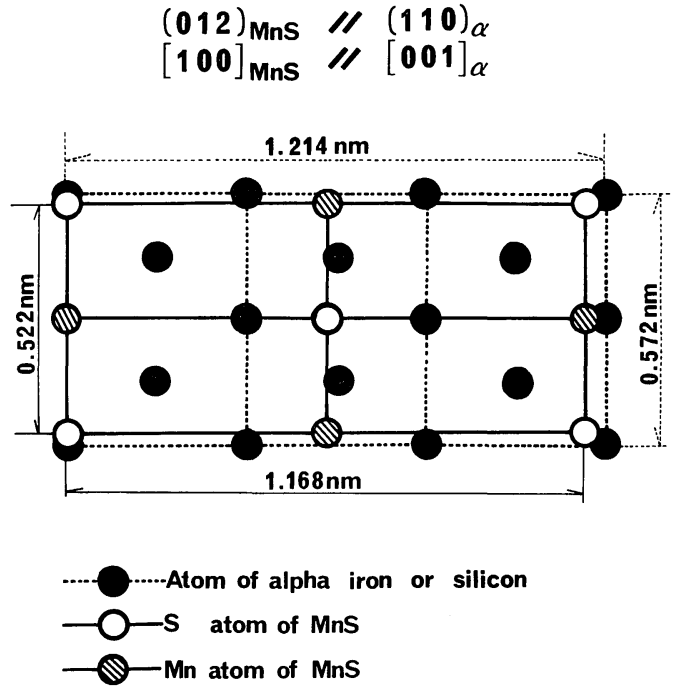

Fig.10 Schematic illustration of the orientation

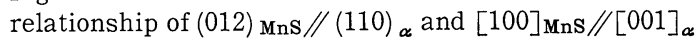
between $\mathrm{MnS}$ and silicon steel matrix.

$\mathrm{MnS}$ と珪素鋼とのずれの程度は $[001]_{\alpha}$ 方向で $8.74 \%$ ， $[1 \overline{1} 0]_{\alpha}$ 方向で $3.80 \%$ でまた整合結晶面の面積のずれは 12\%である。これらの $\mathrm{MnS}$ が鋼板表面近傍に析出したと きの模式図を Fig.8の (e) 亿示すが，MnS は珪素鋼との整 合関係から判断すると鋼板表面に平行ばかりでなく，斜め 方向にも析出している。また $\mathrm{MnS}$ の珪素鋼との整合性も 次報で示す $\mathrm{MnSe}^{(21)}$ 汪ど良好ではない。

\section{V. 結 論}

$\mathrm{MnS}$ をインヒビターとする珪素鋼の仕上焼鈍およびュ 一ティング被膜処理後 $\mathrm{N}_{2}$ 中で焼鈍処理したときの鋼板表 面近傍の $\mathrm{MnS}$ の析出挙動は次のよう飞要約できる.

(1) 約 $0.1 \sim 5 \mu \mathrm{m}$ 程度 (最大 $10 \mu \mathrm{m}$ 長さ) の岩塩型構造 の $\alpha-\mathrm{MnS}$ が鋼板表面近傍に優先析出する.

(2) $\mathrm{MnS}$ は $1073 \mathrm{~K}-1173 \mathrm{~K}$ の温度範囲で $12 \mathrm{ks}$ 以上の焼 鈍により優先析出する。

(3) $5 \mu \mathrm{m}$ 程度の深さに打いて球状と塊状と板状の $\mathrm{MnS}$ が混在する. $10 \mu \mathrm{m}$ 程度の深さでは板状の大きな析出物で
あり， $20 \mu \mathrm{m}$ 深さでは $\mathrm{MnS}$ が小さくなり，数も少なくな る。板厚中心層には $\mathrm{MnS}$ は全く存在しない。

（4）析出物の組成は Mn と S であり，(Mn, Me) S は検 出されない。

(5) $\mathrm{MnS}$ と珪素鋼との整合関係は (1i11) $\mathrm{MnS} / /(110)_{\alpha}$, $[1 \overline{1} \overline{2}]_{\mathrm{MnS}} / /[001]_{\alpha}$ あるいは $(012)_{\mathrm{MnS}} / /(110)_{\alpha},[100]_{\mathrm{MnS}} / /$

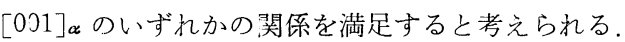

\section{文献}

(1) J.E.May and D.Turnbull : Trans. AIME, 212 (1958), 769 .

(2) S.Taguchi, A.Sakakura, F.Matsumoto, K.Takashima and K.Kuroki : J.Magn. Magn. Mater., 2 (1976) , 121.

（3）清水 洋, 西池氏裕, 佐藤 徹：日本金属学会講演 概要, (1977·10月), p.338.

（4）たと光ば，井口征夫，池田成子，伊藤 庸：特許 出願昭 58-109176 号执よび 58-57916 号。

(5) J.E.Fitz: 特許公告昭 33-9255 号.

(6) W.M.Swift : Metall. Trans., 4 (1973) , 841.

(7) K.Takashima, T.Sato and F.Matsumoto : AIP Conf., Proc. No.29, (1975), p.566.

（8）嶋中 浩, 市田敏郎, 小林 繁: 特許公告昭 5652117 号.

（9）田口 勇：日本金属学会会報，20(1981)，58.

(10) 谷野 満：日本金属学会会報, 22 (1983)，653.

（11）山本厚之, 綿引純雄, 清水真人, 小西元幸 : 日本金 属学会会報, $22(1983) ， 658$.

(12) 角山浩三 : 金属「材料試験 および解析々分析」, 5 月臨時增刊号, (1984)， p.109.

(13) R.Kiessling and C.Westman : J.Iron Steel Inst., 204 (1966) , 377.

(14) N.P.Goss : US Patent, 1965559, (1934) .

(15) M.F.Littman and J.E. Heck:US Patent, 2599340, (1952) .

(16) V.W.Carpenter, S.A.Bell and J.E.Heck : 特許 公告昭 27-2409.

(17) 最初の 2 次再結晶の解説として, 例光ば五弓勇雄, 阿部秀夫：珪素鋼板, コロナ社, (1955)， p.116.

（18）最近の 2 次再結晶機構の解説として, 例えば，井口 征夫 : 鉄と鋼, $70(1984)$, No.15, p.33.

（19）根本 宏, 島田一男, 吉田 成：特許公開昭 55110732 号.

(20) 森戸延行, 杉山甫明, 小畑良夫：特許公開昭 5589423 号.

（21）井口征夫, 筋田成子, 伊藤 庸：日本金属学会誌, $49(1985), 15$ 